\title{
Premature Deaths Due to Silicosis in Turkey, 2006-2017: A Twelve-Year Longitudinal Study
}

\author{
Elif Altundaş Hatman®1', Duygu Acar Karagül@², Eliz Kuman Oyman®², Bahar Tüzün@³, \\ Kadir Onur Şimşek $\mathbb{1}^{2}$, Zeki Kılıçaslan(10 ${ }^{4}$
}

\begin{abstract}
${ }^{1}$ Department of Occupational Medicine, İstanbul Yedikule Chest Diseases and Thoracic Surgery Training and Research Hospital, İstanbul, Turkey
${ }^{2}$ Department of Public Health, İstanbul University, İstanbul School of Medicine, İstanbul, Turkey

${ }^{3}$ Department of Pulmonology, Süreyyapaşa Chest Diseases and Thoracic Surgery Training and Research Hospital, İstanbul, Turkey

${ }^{4}$ Department of Pulmonology, İstanbul University, İstanbul School of Medicine, İstanbul, Turkey
\end{abstract}

Background: Deaths due to epidemics of silicosis still continue to be reported both in developing and developed countries, and silica exposure from different sectors remains an important occupational health concern.

Aims: To identify characteristics of silicosis cases by focusing on a developing country and evaluate the frequency of and factors related to premature deaths and also reveal preventable causes of premature deaths in silicosis.

Study Design: Retrospective cohort.

Methods: We reviewed the records of 9769 patients who were diagnosed with occupational diseases in İstanbul Occupational Diseases Hospital between 2006 and 2017. According to International Classification of Diseases (ICD)-10 codes, 1473 silicosis cases were detected. The sociodemographic characteristics, job characteristics, comorbidities, serological, functional, and radiological data, and follow-up time were obtained from the medical records. Mortality data were gathered from The National Death Notification System of Ministry of Health.

Results: The study examined 9769 cases diagnosed with an occupational disease, and $15.0 \%(\mathrm{n}=1473)$ of them were diagnosed with silicosis. The median age of silicosis patients was 40.0 years, and $26.9 \%$ of them were child labor when they started to work in dusty industries. Child labor was mostly seen among dental technicians (57.7\%), denim sandblasters $(46.4 \%)$, and miners $(37.0 \%)$. In the follow-up period, $26.3 \%$ of Teflon sandblasters, $11.1 \%$ of coal miners, $8.6 \%$ of denim sandblasters had died before their average life expectancy, and the years of loss of life was $26.0 \pm 11.6$ years all over the group. Premature death was associated with occupation [hazard ratio (Teflon sandblasting): 3.93, CI: 1.43-10.78; hazard ratio (marble production): 4.4, CI: 1.02-19.21]; large opacities in posterior anterior chest X-ray [hazard ratio: 2.14, CI: 1.18-3.86]; tuberculosis [hazard ratio: 2.60 , CI: $1.42-$ 4.76]; and reduction in forced vital capacity (forced vital capacity $\%$ $\leq 80$ ) during diagnosis [hazard ratio: 4.43, CI: 2.22-8.83].

Conclusion: More than a quarter of silicosis cases are those who start working in dusty industries at an early age. Factors associated with premature death in patients with silicosis are patient occupation, large opacities on chest X-ray, tuberculosis, and pulmonary function loss at diagnosis.

\section{INTRODUCTION}

Silicosis is an occupational lung disease due to crystalline silica exposure via inhalation, which leads to a range of clinical outcomes including mild pulmonary function loss, mortality, and years of life lost (YLL) as a result of inflammation and fibrosis in the lung parenchyma. ${ }^{1}$
Despite the exposure limit values have been well established and effective prevention measures have been proposed, the worldwide epidemic of silicosis continues. In total, 2.3 million workers in United States, 11.5 million workers in India, and 3-5 million workers in European countries have still been exposed to crystalline silica. ${ }^{2-4}$ At the same time, the pneumoconiosis rate increased

Corresponding author: Elif Altundaş Hatman, Department of Occupational Medicine, İstanbul Yedikule Chest Diseases and Thoracic Surgery Training and Research Hospital, İstanbul, Turkey

e-mail: elifaltundashatman@istanbul.edu.tr

Received: May 3, 2021 Accepted: September 24, $2021 \cdot$ DOI: 10.5152/balkanmedj.2021.21208

Available at www.balkanmedicaljournal.org

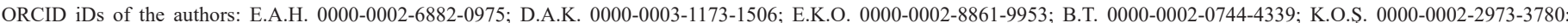
Z.K. 0000-0002-5286-1094.

Cite this article as:

Altundaş Hatman E, Acar Karagül D, Oyman EK, Tüzün B, Şimşek KO, Kılıçaslan Z. Premature deaths due to silicosis in Turkey, 2006-2017: A twelve-year longitudinal study. Balkan Med J. 2021; 38(6):374-381.

Copyright@Author(s) - Available online at http://balkanmedicaljournal.org/ 
$18 \%, 20 \%, 35 \%$, and $33 \%$ between the years of 2013 and 2016 in Turkey. ${ }^{5}$

Even though silicosis is a preventable disease, deaths due to epidemics of silicosis also continue to be reported both in developing and developed countries across various industries and remain an important occupational health concern. Silicosis mortality rate has been found as 28.8 per 100000 person-years, and the high intensity of exposure has also been associated with an increased risk of death in a pooled analysis of 6 cohorts. ${ }^{6}$ Especially intensity of silica exposure, young age, conglomerate masses, smoking, concomitant tuberculosis, and genetic polymorphism in TNF-alpha or desmoplakin gene have been defined as factors increasing mortality in silicosis. ${ }^{7-9}$ Silicosis has also been related with premature deaths, and YLL due to silicosis is 26.5 years before 65 years between the ages of 15 and 44 in the United States. Stone quarrying has the greatest YLL across all the industries in the United States with 23.5 years. ${ }^{10}$

In cases where silicosis could not be prevented completely, it is important to determine the factors affecting premature deaths and to prevent premature deaths in patients with silicosis. Recent studies on the causes of mortality in silicosis concentrate either on the intensity of silica exposure which has been the direct reason for silicosis or reveal irreversible factors such as genetic polymorphism. ${ }^{6,9,11}$ On the other hand, if silicosis has developed, at least avoiding premature deaths and YLL should be prioritized.

Identifying characteristics and differences of silicosis cases in developing countries vis-à-vis developed countries could be important to prevent both the development of silicosis diseases and premature deaths. This study aims to identify characteristics of silicosis cases by giving an example from a developing country and evaluate the frequency of premature deaths, factors related to premature deaths, and also reveal preventable causes of premature deaths in silicosis.

\section{MATERIAL AND METHODS}

This study was designed as a retrospective cohort and conducted between May 2018 and April 2019. Researchers reviewed the records of all patients who had a diagnosis of an occupational disease in İstanbul Occupational Diseases Hospital (IODH) between January 1, 2006, and December 31, 2017. İstanbul Occupational Diseases Hospital was 1 of 3 hospitals for the diagnosis and treatment of occupational diseases in Turkey between 1980 and 2011 and served the provinces in Marmara region and the coastal Aegean cities which have $40 \%$ of total workforce of Turkey. ${ }^{12}$ Some other health institutions were authorized after 2011; however, IODH still is the main health center that diagnoses most of the occupational disease cases in the region.

The ethical approval was obtained from the Ethics Committee of İstanbul University School of Medicine 1630(2018/1602), and research permission was obtained from IODH.

It was found that 9769 people were diagnosed with an occupational disease in IODH during the 12-year period. According to the
ICD-10 code J62.8 (pneumoconiosis due to other dust-containing silica), 1473 silicosis cases were detected among all occupational diseases. The sociodemographic characteristics (gender, age of diagnosis, and smoking status), job characteristics (industry, duration of exposure, and age of first exposure to silica) of patients, comorbidities, functional and radiological data, and follow-up time were obtained from the medical records. Mortality data were gathered from The National Death Notification System of Ministry of Health (NDNSMH).

\section{Definitions and Classification of Data}

Dusty industries were defined based on the history of occupational exposure to silica dust in jobs with high-risk exposure to silica. Dusty industries were classified as denim sandblasting, metal casting and blasting, dental prosthesis production (blasting), ceramic production, ship construction (abrasive blasting), glass production, tunnel construction-stone quarry, coal mining, granite production, Teflon sandblasting, sand production, or others. ${ }^{13}$

Since there is no information about the silica concentration of the workplaces in records, total duration of work in high-risk jobs (years) was used to determine the amount of exposure intensities.

Comorbidities were classified as other occupational diseases (noise-induced hearing loss, lumbar and other intervertebral disc disorders, allergic contact dermatitis, adhesive capsulitis of shoulder, etc.), other pulmonary diseases apart from silicosis and tuberculosis (asthma, chronic obstructive pulmonary disease, bronchitis, etc.), and tuberculosis.

Premature death is the measure of years of potential life lost due to death occurring before the average life expectancy at birth. In death cases, premature deaths and YLL in premature deaths were calculated based on the date of death and life expectancy at birth. Life expectancy values were obtained from "Life expectancy at birth in European countries by sex, 2016" tables published by Turkish National Statistical Office, 2017. ${ }^{14}$ Life expectancy at birth in Turkey was 80.8 years in women and 75.3 years in men in 2017 .

\section{Statistical Analysis}

In descriptive statistics, measures of central distribution and tendency, frequencies and percentages were used. Shapiro-Wilk test was used to test normality. While chi-square test and Fisher's exact test were performed to compare categorical variables, Student's $t$-test and Mann-Whitney $U$-test were used to compare 2 independent groups, and Kruskal-Wallis test was performed to compare more than 2 independent groups because of abnormal distribution. Dunn's test was used for multiple comparisons when the significant result was obtained in the Kruskal-Wallis test as post hoc test. The multivariate Cox proportional hazards regression model was used to explore the independent risk factors associated with premature deaths. Univariate analysis results that were statistically significant were included in the Cox proportional hazard model. Some work activities that can generate respirable silica dust particles are much more hazardous than others. The jobs known with high silica exposure like glass production, granite production, coal mining, denim and Teflon sandblasting were separated from the others so 
6 occupation categories were included in multivariate Cox regression analysis. All predictor variables were entered into the full model, until the best-fitting model (including occupation, tuberculosis, pulmonary function loss, and large opacities in Computed Radiography (CR)) was found.

Results were reported as hazard ratio (HR) for Cox analyses, with $95 \%$ CI in parentheses, and the data were analyzed in SPSS 21.0 program.

\section{RESULTS}

The study examined 9769 cases diagnosed with an occupational disease, and $15.0 \%(n=1473)$ of them were diagnosed with silicosis. The mean age of silicosis patients was $40.4 \pm 10.2$ (17.085.0 ) years, and $26.9 \%$ of them were child labor when they started to work in dusty industries. Child labor was mostly seen in dental technicians $(57.7 \%)$, denim sandblasters $(46.4 \%)$, and miners $(37.0 \%)$.

Distribution of cases according to occupation was as follows: denim sandblasting $21.1 \%(\mathrm{n}=311)$, metal casting sandblasting $16.8 \%(\mathrm{n}=247)$, dental prosthesis production (sandblasting) $13.3 \%$ $(\mathrm{n}=196)$, ceramic production $10.7 \%(\mathrm{n}=157)$, ship construction $7.7 \%(n=110)$, glass production $6.1 \%(n=90)$, tunnel construction-stone quarry $4.1 \%(n=61)$, coal mining 3.8\% $(n=55)$, granite production $1.9 \%(\mathrm{n}=28)$, Teflon sandblasting $1.4 \%(\mathrm{n}=21)$, and sand production $0.8 \%(\mathrm{n}=12)$.

Median exposure duration was 12.0 (4 months to 47 years) years. A quarter of cases $(25.0 \%, \mathrm{n}=362)$ were exposed to silica for 5 years or less, and mean diagnosis age for this group was $33.5 \pm 9.0$ years. One-fifth of all cases $(19.7 \%, n=289)$ were exposed to silica for 6-10 years, and mean diagnosis age for the group was $36.9 \pm 8.6$ years. Half of all cases $(55.4 \%, n=810)$ were exposed to silica for more than 10 years, and mean age at the diagnosis for this group was $44.7 \pm 8.8$ years. Data on pulmonary function tests and International Labour Organization (ILO) classification of patients during diagnosis and comorbidities are shown in Table 1.

Comparison of different occupational groups by some characteristics of workers is given in Table 2. The first exposure age, duration of exposure, diagnosis age, reduction in $\mathrm{FVC}(\mathrm{FVC} \% \leq$ 80 ) at the time of diagnosis, large opacities in posterior anterior chest X-ray (PA-CXR) at the time of diagnosis, premature deaths, and YLL were statistically different between the occupational groups $(P<.001)$. Denim sandblasters were characterized with the second youngest age of first exposure [19.0 (10.0-48.0) years] after dental technicians [17.5 (9.0-37.0) years]. They also had the shortest exposure duration [3.0 (0.3-28.0) years], the youngest age of diagnosis [31.0 (18.0-56.0) year], the second highest rate of reduction in FVC [50.0\% $(\mathrm{n}=152)]$ after Teflon sandblasters $[70.0 \%],{ }^{14}$ the highest rate of having the large opacities during diagnosis $[28.4 \%(\mathrm{n}=87)]$, and the highest YLL [37.1 (18.2$49.5)$ years]. Of all premature deaths, $39.4 \%(n=26)$ were denim sandblasters.
TABLE 1. Cohort Descriptives $(\mathrm{n}=1473)$

\begin{tabular}{|c|c|c|}
\hline & $\mathrm{n}(\%)$ & $\begin{array}{c}\text { Mean }( \pm \text { SD) or Median } \\
\text { (Min-Max) }\end{array}$ \\
\hline \multicolumn{3}{|l|}{ Demographics } \\
\hline \multicolumn{3}{|l|}{ Gender } \\
\hline Female & $9(0.6)$ & \\
\hline Male & $1464(99.4)$ & \\
\hline \multicolumn{3}{|l|}{ Smoking status } \\
\hline Never smoker & $282(19.1)$ & \\
\hline Ex-smoker & $356(24.2)$ & \\
\hline Current smoker & $516(35.0)$ & \\
\hline Unknown & $319(21.7)$ & \\
\hline Tobacco exposure (pack-year) & & $13.0(0.5-130.0)$ \\
\hline \multicolumn{3}{|l|}{ Job characteristics } \\
\hline \multicolumn{3}{|l|}{ Industries } \\
\hline Denim sandblasting & $311(21.1)$ & \\
\hline Metal casting and blasting & $247(16.8)$ & \\
\hline $\begin{array}{l}\text { Dental prosthesis production } \\
\text { (blasting) }\end{array}$ & $196(13.3)$ & \\
\hline Ceramic production & $157(10.7)$ & \\
\hline Ship construction & $110(7.7)$ & \\
\hline Glass production & $90(6.1)$ & \\
\hline $\begin{array}{l}\text { Tunnel construction-stone } \\
\text { quarry }\end{array}$ & $61(4.1)$ & \\
\hline Coal mining & $56(3.8)$ & \\
\hline Granite production & $28(1.9)$ & \\
\hline Teflon sandblasting & $21(1.4)$ & \\
\hline Sand production & $12(0.8)$ & \\
\hline Others & $183(12.4)$ & \\
\hline Age of first exposure (years) & & $23.0(9.0-58.0)$ \\
\hline \multicolumn{3}{|l|}{ Child labor } \\
\hline Yes $(<18$ year old $)$ & $371(26.9)$ & \\
\hline No ( $\geq 18$ year old $)$ & $1006(73.1)$ & \\
\hline Duration of exposure (years) & & $12.0(0.3-47)$ \\
\hline \multicolumn{3}{|l|}{ Pulmonary function tests } \\
\hline FEV $1 \%$ & & $88.0(13.0-139.0)$ \\
\hline $\mathrm{FVC} \%$ & & $90.0(21.0-143.0)$ \\
\hline FEV1/FVC & & $81.0(30.0-113.0)$ \\
\hline \multicolumn{3}{|l|}{ FVC classification } \\
\hline $\mathrm{FVC} \% \leq 80$ & $420(28.9)$ & \\
\hline $\mathrm{FVC} \%>80$ & $1032(71.1)$ & \\
\hline \multicolumn{3}{|l|}{ FEV1/FVC classification } \\
\hline $\mathrm{FEV} 1 / \mathrm{FVC} \geq 70$ & $1249(86.2)$ & \\
\hline FEV1/FVC $<70$ & $200(13.8)$ & \\
\hline \multicolumn{3}{|l|}{ ILO classification } \\
\hline Category 1 & $666(45.6)$ & \\
\hline Category 2 & $400(27.4)$ & \\
\hline Category 3 & $216(14.8)$ & \\
\hline
\end{tabular}

(Continued) 
TABLE 1. Cohort Descriptives $(\mathrm{N}=1473)$ (Continued)

\begin{tabular}{lcc}
\hline & $\mathrm{n}(\%)$ & $\begin{array}{c}\text { Mean }( \pm \text { SD) or Median } \\
(\text { Min-Max })\end{array}$ \\
\hline Large opacities & $177(12.1)$ & \\
Comorbidities & $164(18.1)$ & \\
Pulmonary comorbidity & $278(18.9)$ & \\
Occupational comorbidity & $109(7.6)$ & \\
Tuberculosis & & \\
Survival & & \\
Age of diagnosis (years) & & \\
Duration of silicosis (months) & & \\
Survival & & \\
Dead & & \\
Alive & & \\
Unknown & & \\
Age of death & & \\
YLL & & \\
Second examination & & \\
Yes & & \\
No & & \\
\hline
\end{tabular}

Missing variables were not analyzed so column percentages of available variables are given in the table. FEV, Forced Expiratory Volume; FVC, forced vital capacity; YLL, years of life lost.

At least 76 patients $(5.2 \%$ of all patients) had died, and $86.8 \%$ $(n=66)$ of them were premature deaths, $4.5 \%$ of silicosis patients had died before their average life expectancy. In the follow-up period, $26.3 \%(n=5)$ of teflon sandblasters, $11.1 \%(n=6)$ of coal miners, $8.6 \%(n=26)$ of denim sandblasters had died before their average life expectancy and the YLL was $26.0 \pm 11.6$ years all over the group. Bivariate analyses indicated that the occupation (Teflon sandblasters $)(P<.001)$, short duration of exposure $(P<.002)$, reduction in FVC $(P<.001), \mathrm{FEV} 1 / \mathrm{FVC}<70(P<.001)$, large opacities in PA-CXR $(P<.001)$, comorbid pulmonary diseases $(P<.001)$, and tuberculosis $(P<.001)$ were associated with premature death. Comparison of premature death and others according to some characteristics are shown in Table 3.

The results of the Cox regression analysis are presented in Table 4. The occupation [HR (Teflon sandblasting): 3.93, CI: 1.43-10.78; HR (granite production): 4.4, CI: 1.02-19.21]; large opacities in PA-CXR [HR: 2.14, CI: 1.18-3.86]; tuberculosis [HR: 2.60, CI: 1.42-4.76]; and reduction in FVC (FVC\% $\leq 80)$ during diagnosis [HR: 4.43, CI: 2.22-8.83] were all associated with premature death. The short duration of exposure time, FEV1/FVC $<70$ during diagnosis, and comorbid pulmonary diseases were found to be associated with premature death in bivariate analyses; however, no significant association between them and premature death was found in Cox regression.

\section{DISCUSSION}

More than a quarter of silicosis cases were child labor when they started to work in dusty industries. At least $5.2 \%$ of silicosis patients had died and $4.5 \%$ of silicosis patients also had died before their average life expectancy and the YLL was 26.0 years in followup period in this study. Especially, sandblasters are under the risk of premature deaths of silicosis. This study shows the relationship among patient premature deaths and occupation, large opacities in PA-CXR, tuberculosis, and pulmonary function loss.

ILO reported that the 73 million children between the age of 5 and 17 years work in hazardous industries, mostly including construction, mining and manufacturing industries, which increase the

TABLE 2. Comparison of Different Occupational Groups by Some Characteristics of Workers

\begin{tabular}{|c|c|c|c|c|c|c|}
\hline & $\begin{array}{l}\text { Age of First Exposure } \\
\text { (Years) }{ }^{\dagger}, \text { Median } \\
\text { (Min-Max) }\end{array}$ & $\begin{array}{c}\text { Duration of Exposure } \\
\text { (Years) }{ }^{\dagger} \text {, Median } \\
\text { (Min-Max) }\end{array}$ & $\begin{array}{c}\text { Age of Diagnosis } \\
\text { (Year-old })^{\dagger}, \text { Median } \\
(\text { Min-Max })\end{array}$ & $\begin{array}{c}\mathrm{FVC} \% \leq \\
80^{*}, \%(\mathrm{~N})\end{array}$ & $\begin{array}{c}\text { Large Opacities }{ }^{\ddagger}, \\
\%(\mathrm{~N})\end{array}$ & $\begin{array}{l}\text { Years of Lost Life } \\
{\text { (Years) }{ }^{\dagger}, \text { Median }}^{(\text {Min-Max) }}\end{array}$ \\
\hline Denim sandblasting & $19.0(10.0-48.0)^{*}$ & $3.0(0.3-28.0)^{*}$ & $31.0(18.0-56.0)^{*}$ & $50.0(152)^{*}$ & $28.4(87)^{*}$ & $37.1(18.2-49.5)^{*}$ \\
\hline Metal casting and blasting & $26.0(12.0-49.0)$ & $12.0(1.0-44.0)$ & $41.0(26.0-65.0)$ & $18.6(46)$ & $3.6(9)$ & $21.1(8.2-42.6)$ \\
\hline $\begin{array}{l}\text { Dental prosthesis production } \\
\text { (blasting) }\end{array}$ & $17.5(9.0-37.0)^{*}$ & $20.0(2.0-47.0)$ & $40.0(22.0-67.0)$ & $23.8(46)$ & 9.9 (19) & $31.3(18.3-40.9)^{*}$ \\
\hline Ceramic production & $24.0(16.0-48.0)$ & $17.0(2.0-33.0)$ & $43.0(27.0-70.0)$ & $15.5(24)$ & $3.2(5)$ & $27.1(21.5-34.4)$ \\
\hline Ship construction & $24.0(11.0-48.0)$ & $15.0(1.0-40.0)$ & $42.0(17.0-67.0)$ & $15.7(17)$ & $0.9(1)$ & 20.0 \\
\hline Glass production & $24.0(13.0-50.0)$ & $15.5(0.8-33.0)$ & $43.0(25.0-70.0)$ & $28.4(25)$ & $17.8(16)$ & $20.6(6.3-41.3)$ \\
\hline $\begin{array}{l}\text { Tunnel construction-stone } \\
\text { quarry }\end{array}$ & $25.0(13.0-43.0)$ & $17.0(1.0-30.0)$ & $49.1(28.0-77.0)$ & $37.7(23)$ & $27.9(17)^{*}$ & $18.7(5.5-32.0)$ \\
\hline Coal mining & $21.0(15.0-50.0)$ & $20.0(1.0-39.0)$ & $57.0(24.0-85.0)$ & $49.1(26)^{*}$ & $14.8(8)$ & $9.0(3.3-33.1)$ \\
\hline Marble production & $23.0(13.0-40.0)$ & $19.0(2.0-33.0)$ & $43.0(22.0-65.0)$ & $35.7(10)$ & $10.7(3)$ & $30.6(19.0-42.2)^{*}$ \\
\hline Teflon sandblasting & $27.0(12.0-48.0)$ & $10.0(2.0-16.0)$ & $41.5(26.0-54.0)$ & $70.0(14)^{*}$ & $19.0(4)$ & $22.1(20.1-33.4)$ \\
\hline Sand production & $23.0(15.0-36.0)$ & $15.0(3.0-32.0)$ & $41.0(27.0-55.0)$ & $25.0(3)$ & $25.0(3)$ & - \\
\hline Others & $24.0(10.0-58.0)$ & $13.0(1.0-45.0)$ & $41.0(24.0-64.0)$ & $18.6(34)$ & $2.7(5)$ & $16.7(8.0-44.0)$ \\
\hline
\end{tabular}

$* P<.001$

${ }^{\dagger}$ Kruskal- Wallis test [Table does not include ranks so measures of central tendency (median, maximum, and minumum) are given.]. ${ }^{\star}$ Chi-square test. 
TABLE 3. Comparison of Premature Death With Others by Some Characteristics $(n=1459)$

\begin{tabular}{|c|c|c|c|c|c|}
\hline & \multicolumn{2}{|c|}{ Premature Death $(n=66)$} & \multicolumn{2}{|c|}{ Others $(n=1393)$} & \multirow[b]{2}{*}{$P$} \\
\hline & $\mathrm{N}(\%)$ & $\begin{array}{c}\text { Mean }( \pm \text { SD) or Median } \\
\text { (Min-Max })\end{array}$ & $\mathrm{N}(\%)$ & $\begin{array}{c}\text { Mean }( \pm \text { SD) or Median } \\
(\text { Min-Max })\end{array}$ & \\
\hline Age of diagnosis & & $41.8 \pm 12.0$ & & $40.4 \pm 10.1$ & $.277^{\dagger}$ \\
\hline Duration of silicosis (months) & & $50(4-335)$ & & $60(4-348)$ & $.001^{\ddagger}$ \\
\hline \multicolumn{6}{|l|}{ Job characteristics } \\
\hline \multicolumn{6}{|l|}{ Occupation } \\
\hline Denim sandblasting & $26(8.5)$ & & $281(91.5)$ & & $<.001^{\natural}$ \\
\hline Metal casting and blasting & $8(3.2)$ & & $240(96.8)$ & & \\
\hline Dental prosthesis production (blasting) & $5(2.6)$ & & $191(97.4)$ & & \\
\hline Ceramic production & $3(1.9)$ & & $153(98.1)$ & & \\
\hline Ship construction & $1(0.9)$ & & $109(99.1)$ & & \\
\hline Glass production & $6(6.8)$ & & $82(93.2)$ & & \\
\hline Tunnel construction-stone quarry & $2(3.4)$ & & $57(96.6)$ & & \\
\hline Coal mining & $5(8.9)$ & & $51(91.1)$ & & \\
\hline Granite production & $2(7.1)$ & & $26(92.6)$ & & \\
\hline Teflon sandblasting & $5(26.3)$ & & $14(73.7)$ & & \\
\hline Sand production & $0(0.0)$ & & $12(100.0)$ & & \\
\hline Others & $3(1.7)$ & & $177(98.3)$ & & \\
\hline Age of first exposure & & $23(12-49)$ & & $23(9-58)$ & $.901^{\ddagger}$ \\
\hline Duration of exposure & & $6.0(0.8-33.0)$ & & $12.0(0.3-47.0)$ & $.002^{\ddagger}$ \\
\hline \multicolumn{6}{|l|}{ Pulmonary function tests } \\
\hline FEV1\% & & $50(19-116)$ & & $89(13-139)$ & $<.001^{\ddagger}$ \\
\hline $\mathrm{FVC} \%$ & & $63(21-123)$ & & $91(23-143)$ & $<.001^{\ddagger}$ \\
\hline FEV1/FVC & & $74(43-112)$ & & $81(30-113)$ & $<.001^{\ddagger}$ \\
\hline \multicolumn{6}{|l|}{$\mathrm{FVC} \%$ classification } \\
\hline $\mathrm{FVC} \% \leq 80$ & $51(12.3)$ & & $363(87.7)$ & & $<.001^{\S}$ \\
\hline $\mathrm{FVC} \%>80$ & $12(1.2)$ & & $1013(98.8)$ & & \\
\hline \multicolumn{6}{|l|}{ FEV1/FVC classification } \\
\hline$\geq 70$ & $41(3.3)$ & & $1197(96.7)$ & & $<.001^{\S}$ \\
\hline$<70$ & $21(10.6)$ & & $177(89.4)$ & & \\
\hline \multicolumn{6}{|l|}{ Large opacities in PA-CXR } \\
\hline Yes & $33(18.8)$ & & $143(81.2)$ & & $<.001^{\S}$ \\
\hline No & $31(2.4)$ & & $1238(97.6)$ & & \\
\hline \multicolumn{6}{|l|}{ Comorbidities } \\
\hline \multicolumn{6}{|l|}{ Pulmonary comorbidity } \\
\hline Yes & $21(8.0)$ & & $243(92.0)$ & & $<.001^{\S}$ \\
\hline No & $37(3.2)$ & & $1134(96.8)$ & & \\
\hline \multicolumn{6}{|l|}{ Tuberculosis } \\
\hline Yes & $18(16.5)$ & & $91(83.5)$ & & $<.001^{\S}$ \\
\hline No & $39(2.9)$ & & $1286(97.1)$ & & \\
\hline
\end{tabular}

Row percentages are given in the table. FVC, forced vital capacity; PA-CXR, posterior anterior chest X-ray.

${ }^{\dagger}$ Student's $t$-test; ${ }^{\star}$ Mann-Whitney $U$-test; ${ }^{\circledR} \mathrm{Chi}$-square test; 'Fisher's exact test.

risk of the development of silicosis. ${ }^{15}$ Although it is estimated that child labor is common in industries with high risk of silicosis in both developing and undeveloped countries, only a limited number of studies revealed the real aspect. In Brazil, $44.7 \%$ of silicosis cases worked as stone polishers and miners, and in Turkey, similarly $45.2 \%$ of silicosis cases worked as denim sandblasters who had begun sandblasting before they were 18 years of age. ${ }^{16,17}$ As shown in this study, child labor was seen in approximately 6 in 
TABLE 4. Cox Regression Analysis of Premature Deaths in Silicosis

\begin{tabular}{|c|c|c|}
\hline & $\operatorname{HR}(95 \% \mathrm{CI})$ & $P$ \\
\hline \multicolumn{3}{|l|}{ Occupation } \\
\hline Others* & 1 & \\
\hline Glass production & $1.56(0.53-4.60)$ & .418 \\
\hline Granite production & $4.44(1.02-19.21)$ & $.046^{* *}$ \\
\hline Denim sandblasting & $1.08(0.57-2.05)$ & .799 \\
\hline Coal mining & $1.11(0.25-4.82)$ & .883 \\
\hline Teflon sandblasting & $3.93(1.43-10.78)$ & $.008^{* *}$ \\
\hline \multicolumn{3}{|l|}{ Tuberculosis } \\
\hline $\mathrm{No}^{*}$ & 1 & \\
\hline Yes & $2.60(1.42-4.76)$ & $.002^{* *}$ \\
\hline \multicolumn{3}{|l|}{ Pulmonary function loss } \\
\hline $\mathrm{FVC} \%>80^{*}$ & 1 & \\
\hline $\mathrm{FVC} \% \leq 80$ & $4.43(2.22-8.83)$ & $<.001^{* * *}$ \\
\hline \multicolumn{3}{|l|}{ Large opacities in CR } \\
\hline $\mathrm{No}^{*}$ & 1 & \\
\hline Yes & $2.14(1.18-3.86)$ & $.011^{* *}$ \\
\hline
\end{tabular}

10 dental technicians followed by nearly half of denim sandblasters and more than 1 in 3 miners in all silicosis cases. This study does not only show that child labor in dusty industries results in a high rate of silicosis but also shows that the rate of child labor is very high among dental technicians with silicosis, which has not been previously identified as a risky industry for intensive child labor. The fact that these workers began to work when they were still children should serve as a warning for public authorities, and they should take more effective and deterrent actions to prevent child labor.

Although there have been case series and case notifications from different sectors in recent years, ${ }^{16,18-20}$ silicosis cases are seen more frequently in traditional industries like mining, drilling, quarrying, ceramic production, and construction which are known to be related with silicosis ${ }^{21,22}$ However, in our study, approximately $60 \%$ of all cases were from sandblasting-derived industries such as denim sandblasting, metal casting and sandblasting, dental prosthesis production (sandblasting), ship construction (abrasive blasting), and Teflon sandblasting. The results show the industrial distribution of silicosis cases in a developing country. Similarly, a recent study in China found that the ferrous metal processing industry is one of the industries where silicosis cases were found the most. ${ }^{21}$ These results may be related to the fact that silicosis is seen less frequently as a result of implementing occupational health and safety regulations in the traditional industries compared with the new industries which do not provide adequate occupational health and safety conditions.

Despite the short-term exposure and the young age of diagnosis, the highest rate of reduction in $\mathrm{FVC}$, the highest rate of large opacities, and the greatest YLL in all occupational groups should be related to intensive exposure to silica in sandblasters in our study. On the other hand, previous research shows that the freshly fractured silica formed during sandblasting is more likely to produce free radicals, hence its fibrogenic potential is also higher, which may explain both the highest rate of sandblasting activities in silicosis cases and large opacities in sandblasters in the study. ${ }^{23,24}$

After the outbreak of silicosis in Turkey, denim sandblasting was banned, ${ }^{25}$ however, sandblasting still continues in other industries. Sandblasting is a hazardous method for human health which is used to make clean surfaces in various industries; it can be substituted by alternative methods.

Within the scope of the research, cause-specific mortality rate could not be calculated and discussed, since researchers were not given access to NDNSMH for cause-specific mortality. Therefore, premature death, another important measurement which refers to the measure of years of potential life lost due to death occurring before the average life expectancy at birth, was used as the output of the research.

At least $5.2 \%$ of silicosis patients had died and $4.5 \%$ of silicosis patients also had died before their average life expectancy and the YLL was 26.0 years in the follow-up period in this study. In China, it is similarly reported that silicosis has the highest mean YLL with an average of 22.1 years. ${ }^{26}$ In total, pneumoconiosis- and silicosis-related YLL was 26.5 years according to Centers for Diseases Control and Prevention weekly report, and stone products had the greatest YLL with 23.5 years across all the industries. ${ }^{10,26}$ The study revealed that denim sandblasters who started working in young ages may have the greatest YLL due to deaths in denim sandblasters from subacute or accelerated silicosis. According to another study, $6.2 \%$ of denim sandblasters died at a mean age of 24 years in the 4 years follow-up period. ${ }^{27}$

Another limitation of the research is the absence of data on silica exposure intensities. However, this study shows that there is a significant relationship between the duration of exposure and the age of diagnosis. This may be related to the appearance of disease at a young age with a short duration but intense exposure. Previous studies also point out that workers in traditional industries may develop chronic silicosis with a slow progression due to low exposure intensity. On the contrary, in other industries, workers may be diagnosed with acute and accelerated silicosis over a short period of time, due to high-intensity silica concentrations. ${ }^{28}$

This study yielded that Teflon sandblasters have 3.93 times, workers who work in granite industry have 4.40 times, silicosis patients with large opacities in PA-CXR have 2.14 times, cases with silicotuberculosis have 2.60 times, and patients with a decreased pulmonary function during diagnosis have 4.43 times increased risk for premature death.

Some industries could be riskier for premature deaths because of high-intensive exposure to silica. This study shows an association between some occupations (Teflon sandblasting, granite 
production) and premature deaths. On average, granite naturally contains $70-77 \%$ crystalline silica by weight. ${ }^{29}$ Sandblasting of Teflon pan manufacturing causes commonly acute form of silicosis, and mortality was high. ${ }^{30}$

Large opacities in PA-CXR are caused by the large conglomerate masses of dense fibrosis is called progressive massive fibrosis (PMF) and reduced the respiratory functions of smokers and non-smokers in a major way. National Institute for Occupational Safety and Health reported $10 \%$ of coal miners and another study showed $9.6 \%$ of denim sandblasters had large opacities in PA-CXR. ${ }^{16,31}$ In this study, it was determined that $12.1 \%$ cases had large opacities in PA-CXR, and having large opacities increases the risk of premature death 2.14 times. In a study conducted with silicosis patients, it was determined that patients who had profusion category 2, 3 and large opacities had higher risk of mortality and type $\mathrm{C}$ opacity had the highest risk with standardized mortality ratio $8.92 .{ }^{8}$ Development of large opacities in silicosis patients reduces the quality of life and more importantly can lead to premature death. New studies and further research are needed to determine which silicosis patients have higher risk of developing PMF. Since there is no treatment for silicosis as of today, these patients should be monitored more frequently.

It has been determined that people with silicosis had 2.8-39 times higher risk of having tuberculosis compared to healthy individuals. ${ }^{3,31}$ Among silicosis patients, incidence of active tuberculosis has been found as $32 \%$ and the prevalence of latent tuberculosis has been shown to be $46.6-61 \% .^{32}$ In our study, frequency of tuberculosis cases seems to be lesser compared to other countries. This might be due to decrease in incidence of tuberculosis in Turkey, or it might be caused by data deficiencies. Tuberculosis mortality rate in silicosis patients is being discussed through numerous studies. Silicosis cases with tuberculosis have 3.75 times higher risk of death. ${ }^{19}$ In United States, 13.7\% patients who died from silicosis was also diagnosed with tuberculosis between 1968 and 2006. ${ }^{33}$ This study shows that among 109 participants, tuberculosis resulted in premature death for $16.5 \%$ of the individuals, and risk of premature death has increased 2.6 times for individuals who had tuberculosis.

Silicosis increases the risk of tuberculosis, and silicotuberculosis increases the risk of death. However, the fact that both of the diseases are preventable yet they continue to take lives is thought provoking. In silicosis cases, precautions must be taken before tuberculosis occurs, and every case must be inspected carefully for latent tuberculosis infection. Necessary tests must be performed, and patients who have been deemed suitable must start preventive treatment.

The studies indicate that reduced lung function was more likely to be associated with higher categories of silicosis (ILO 3) than with lower categories; however, in our study, both reduced lung function and large opacities in PA-CXR are associated with premature death as independent variables. The risk of premature death increases 4.43 times for cases whose reduction in $\mathrm{FVC} \% \leq 80$ during diagnosis. Reduction in FVC at the beginning should be a warning sign for clinicians.

More than a quarter of silicosis cases were child labor when they started to work in dusty industries. This should serve as a warning for public authorities who should take more effective and deterrent actions to prevent child labor. Sandblasters are under the risks of premature death due to silicosis. This study shows the relationships among patient premature deaths, occupation, large opacities in PACXR, tuberculosis, and pulmonary function loss. More attention should be given to tuberculosis prevention in silicosis.

Ethics Committee Approval: The ethical approval was obtained from the Ethics Committee of İstanbul University School of Medicine 1630(2018/1602) and research permission from IODH.

Patient Consent for Publication: N/A.

Data-sharing Statement: The data that support the findings of this study are available from the corresponding author upon reasonable request.

Author Contributions: Concept - E.A.H., Z.K.; Design - E.A.H.; Supervision - E.A.H.; Data Collection and/or Processing - D.A.K., E.K.O., B.T., K.O.Ş.; Analysis and/or Interpretation - E.A.H., D.A.K., E.K.O., B.T., K.O.Ş.; Literature Review - E.A.H., D.A.K., E.K.O., B.T.; Writing - E.A.H., D.A.K., E.K.O., B.T.; Critical Review - E.A.H., Z.K.

Conflict of Interest: The authors have no conflicts of interest to declare.

Funding: The authors declared that this study has received no financial support.

\section{REFERENCES}

1. Centers for Disease Control and Prevention (CDC). Health Effects of Occupational Exposure Respirable Crystalline Silica [DHHS (NIOSH) Publication No. 2002-129]. Cincinnati, OH: The National Institute for Occupational Safety and Health (NIOSH); 2002.

2. Centers for Disease Control and Prevention (CDC). Preventing silicosis. Available at: https://www.cdc.gov/features/preventing-silicosis/index.html, Accessed June 13, 2019.

3. Jindal SK. Silicosis in India: past and present. Curr Opin Pulm Med. 2013;19(2):163168. [CrossRef]

4. De Matteis S, Heederik D, Burdorf A, et al. Current and new challenges in occupational lung diseases. Eur Respir Rev. 2017;26(146). [CrossRef]

5. Akgün M, Ergan B. Silicosis in Turkey: is it an endless nightmare or is there still hope? Turk Thorac J. 2018;19(2):89-93. [CrossRef]. Erratum in: Editorial Office Staff TTJ. Erratum. Turk Thorac J. 2018;19(3):158. [CrossRef]

6. Mannetje A, Steenland K, Attfield M, Boffetta P, Checkoway H, DeKlerk N. Exposure-response analysis and risk assessment for silica and silicosis mortality in a pooled analysis of six cohorts. Occup Environ Med. 2002;59(11):723-728. [CrossRef].

7. Greenberg MI, Waksman J, Curtis J. Silicosis: a review. Dis Mon. 2007;53(8):394 416. [CrossRef]

8. Ng TP, Chan SL, Lee J. Predictors of mortality in silicosis. Respir Med 1992;86(2):115-119. [CrossRef]

9. Wang W, Yu Y, Xiao J, et al. A novel variant of desmoplakin is potentially associated with silicosis risk. DNA Cell Biol. 2018;37(11):925-931. [CrossRef]

10. Centers for Disease Control and Prevention (CDC). Silicosis-related years of potential life lost before age 65 years-United States, 1968-2005. MMWR Morb Mortal Wkly Rep. 2008;57(28):771-775. Erratum in: MMWR Morb Mortal Wkly Rep. 2008;57(30):829.

11. Liu Y, Zhou Y, Hnizdo E, et al. Total and cause-specific mortality risk associated with low-level exposure to crystalline silica: a 44-year cohort study from China. Am J Epidemiol. 2017;186(4):481-490. [CrossRef] 
12. Bilir N. Occupational Safety and Health Profile: Turkey. 1st ed. Ankara, Turkey: International Labour Organization (ILO); 2016.

13. De Vuyst P, Camus P. The past and present of pneumoconioses. Curr Opin Pulm Med. 2000;6(2):151-156. [CrossRef]

14. Turkish National Statistical Office. "Life expectancy at birth in European countries by sex, 2016" tables. 2017. Available at: http://www.tuik.gov.tr/UstMenu.do?metod= temelist, Accessed April 30, 2019.

15. International Labour Office (ILO). Global Estimates of Child Labour: Results and Trends, 2012-2016 [Report]. Geneva: ILO; 2017.

16. Akgun M, Araz O, Akkurt I, et al. An epidemic of silicosis among former denim sandblasters. Eur Respir J. 2008;32(5):1295-1303. [CrossRef]

17. Chiavegatto CV, Carneiro APS, Dias EC, Nascimento MS. Diagnosis of severe silicosis in young adults working in stone polishing and mining in Minas Gerais, Brazil. Int J Occup Environ Health. 2010;16(2):139-142. [CrossRef]

18. Blanco Pérez JJ, Arnalich Montiel V, Salgado-Barreira Á, et al. The 6-minute walk test as a tool for determining exercise capacity and prognosis in patients with silicosis [in Spanish]. Arch Bronconeumol. 2019;55(2):88-92. [CrossRef]

19. Jiang CQ, Xiao LW, Lam TH, Xie NW, Zhu CQ. Accelerated silicosis in workers exposed to agate dust in Guangzhou, China. Am J Ind Med. 2001;40(1):87-91. [CrossRef]

20. Hoy RF, Baird T, Hammerschlag G, et al. Artificial stone-associated silicosis: a rapidly emerging occupational lung disease. Occup Environ Med. 2018;75(1):3-5. [CrossRef]

21. Liu J, Feng LM, Tang HJ, et al. The epidemiological characteristics of silicosis cases in Tianjin from 2001 to 2015 [in Chinese]. Zhonghua Lao Dong Wei Sheng Zhi Ye Bing Za Zhi. 2019;37(5):366-369. [CrossRef]

22. Xie LZ, Zhou L, Ding BM, et al. Analysis of occupational pneumoconiosis in Jiangsu Province from 2006 to 2017 [in Chinese]. Zhonghua Lao Dong Wei Sheng Zhi Ye Bing Za Zhi. 2019;37(3):189-193. [CrossRef]
23. Fubini B, Hubbard A. Reactive oxygen species (ROS) and reactive nitrogen species (RNS) generation by silica in inflammation and fibrosis. Free Radic Biol Med. 2003;34(12):1507-1516. [CrossRef]

24. Vallyathan V, Shi XL, Dalal NS, Irr W, Castranova V. Generation of free radicals from freshly fractured silica dust: potential role in acute silica-induced lung injury. Am Rev Respir Dis. 1988;138(5):1213-1219. [CrossRef]

25. Bakan ND, Özkan G, Çamsari G, et al. Silicosis in denim sandblasters. Chest. 2011;140(5):1300-1304. [CrossRef]

26. Zhong Y, Li D. Potential years of life lost and work tenure lost when silicosis is compared with other pneumoconioses. Scand J Work Environ Health. 1995;21(suppl 2):91-94.

27. Akgun M, Araz O, Ucar EY, et al. Silicosis appears inevitable among former denim sandblasters. Chest. 2015;148(3):647-654. [CrossRef]

28. Barnes H, Goh NSL, Leong TL, Hoy R. Silica-associated lung disease: an old-world exposure in modern industries. Respirology. 2019;24(12):1165-1175. [CrossRef]

29. Arrouays D, McKenzie N, Hempel J, de Forges AR, McBratney BA. Global Soil Map: Basis of the Global Spatial Soil Information System. 1st ed. Boca Raton, FL: CRC Press; 2014.

30. Köksal N, Kahraman H. Acute silicosis in teflon-coated pan manufacturing due to metal sandblasting. Int J Occup Environ Health. 2011;17(3):210-213. [CrossRef]

31. Blackley DJ, Halldin CN, Laney AS. Continued increase in prevalence of coal workers' pneumoconiosis in the United States, 1970-2017. Am J Public Health. 2018;108(9):1220-1222. [CrossRef]

32. Farazi A, Jabbariasl M. Silico-tuberculosis and associated risk factors in central province of Iran. Pan Afr Med J. 2015;20:333. [CrossRef]

33. Nasrullah M, Mazurek JM, Wood JM, Bang KM, Kreiss K. Silicosis mortality with respiratory tuberculosis in the United States, 1968-2006. Am J Epidemiol. 2011;174(7):839-848. [CrossRef] 